\title{
Design and Analysis: Payroll of Accounting Information System
}

\author{
Suryanto
}

\begin{abstract}
Purpose of the research are to analyze, design, and recommended the payroll of accounting information system that support the internal control to solve the problem. Research methods used are book studies, field studies, and design studies. Fields studies done by survey and interview. The expected result are to give a review about the payroll of accounting information system in the ongoing business process of company and to solve all the weakness in the payroll system, so the company can use the integrated information system in counting of the payroll. Conclusion that can take from the research are there's some manipulation risk of attendance data and documentation of form still using a manual system and simple data backup. Then, there's also manipulation risk in allowance cash system and all the report that include in the payroll.
\end{abstract}

Index Terms - Accounting Information System, Payroll

\section{INTRODUCTION}

$\mathrm{I}_{\mathrm{b}}^{\mathrm{n}}$ globalization era, there's many competition to lead the business in the company. All the competition needs a valid information system to be used by the management to make a right decision that will decide the rights and increase the company performance and become a leader from all the company that in the same type of business.

According to Sajady et al.[3], Usage of accounting information systems (AIS) is crucial and defined it as a computer based system will support the decision task in control the operational activities in the company. The effectiveness of using AIS depends into the perception of usefulness the information that generate by the system and it analyzed into three bases, such scope, time, and aggregation. Beside that, using an AIS could lead a better decision making of manager, effectively in transaction process and internal control, enhance the qualityof report and improve the performance measures. According to $\mathrm{Xu}$, AIS is a critical system in the way of capturing, processing, storing and distribution of information, and AIS show the relationship between the system, stakeholder of the company, and the organizational factor with the data to help better understanding of the system.

This research would be in A. hotel that haven't use a computerized system and they make many uncertainty in the payroll system between the attendance time and counting on employee payroll, this situation will impact to the report of the payroll, so this hotel need a system that integrated with the information system and give the positive impact to the counting of payroll.

\section{Research Method}

Research method used in this research divided into three method, they are book studies, field studies, and design studies. Book studies by getting the information from books, journal, and procedure in many sources. Field studies done by survey through the company, and doing an interview to the person who turns into the payroll systedirectly. Then, for design method used an Object Oriented Analysis and Design, that will divided into 12 phases, such a rich pictures, event table, workflow table, overview activity diagram, detailed activity diagram, UML class diagram, use case diagram, navigation diagram, database design, form design, and interface design.

\section{Literature Review}

According to Salehi et al [4], AIS are focused on recording, summarizing, and validating the datainto transaction and it performs in various groups which concerned of making decision in financial, managerial and tax compliance issue. The effectiveness of AIS can provide a profitably on major concern to the company and widely used to satisfy the user and improves the quality of company's performance. AIS created a business directly to the organizational culture, level strategic planning and the information technologies that has a specific in business, AIS also plays an important roles on managing the enterprise activities, and it can provide the management information to assist a decision to the successful managing and the company will achieve the goals. There's some advantage from using the AIS method:

- Good corporation, all the things happen always linked to the certain environment even the third parties that exist in the market, but there's still no maintain of relationship. The new system will record and reflect all the company's parts and all the things done by the internet.

- To meet the needs of multi-users. It different between the traditional system and new system used now. In traditional system, the IS system only generate the financial statement and it makes the uses of object become narrow, but in the new system all the resources will be record through the database system and make it integrated based on the computer system, so the new system make the all the data complex and can reduce the lack and un valid data

- To control afterwards, and control in advance and in concurrent, the new IS will help the company to reduce the cost and all the system will integrate in the real time processing, so all the target of company can be achieved in the standard cost and will depends on time schedule.

According to Grande et al.[1], AIS will show that 
computerized accounting tools are directly will connect to the result and productivity of the business organization in the company, AIS will combines a methodology control and techniques in the company through the IT, such a user interface, computers, and sophisticated software. AIS will help for better adaptation in changing environment, better management, and high degree competitive. AIS help the company to reduce the cost and increase the company's productivity by the innovation. IT innovation that adopted by the company will increase their performance even in the financial and operational, and the productivity will be analyzed in three components: efficiency, technological change, and change of scale, which has not been a part of company.

According to Sori [5], AIS separately in two ways, first into literature document that defined into three components which are namely IS, language of business, and source of IS. Then, into a valuable data processing to process the making of decision by the management. AIS works in the integrated business which design specially for the company and it will generate the financial data to be analyzed by the accountants to be used in the top level of management to take a right decisions and identify the opportunities that company could take in the company. There are also some of AIS users in the company, they are such as the Financial Accountants, Management Accountants and Finance Manager are the internal users of the system. Also, the management team that consists of Finance General Manager, Chief Operating Officer, Managing Director and Board of Directors are among the internal users of the system. AIS will also provide an information on actual and budget data of the company and help the management to control the business, and AIS will also played the crucial roles that contribute to the value added by provide the internally generated input from the financial statement.

According to the Mauldin (1999), AIS will help to diverse with a potential for exploring in many different interrelationship such a technical, organizational, and individual aspect on making decision, it also process the transaction which happened in many aspect of company (ex. Auditing, financial, managerial, and tax), and also will recognized the fundamental changing task process and in decision support to increase the speed of accounting tasks.

\section{Internal Problem}

Problems from ongoing system in the company are listed below.

In the employee attendance procedure, there's still any risk happened in doing cheating like a data manipulation of the employee attendance, this situation happened because the record of attendance still using a manual system

In the allowance payment system, company still using a cash payment. In this side, we can see from the Personnel and administration supervisor, then distributed it into the employees. This things are risky for a company, because there's any possibility for Personel and Administrator supervisor to make discrepancy. Beside that, there's any risk come from the external factor, where the things happened related to the security of the funding. So, the company will get any loss that will impact to the financial company.
There's no document about an employee performance assessment and the company doesn't have any procedure to assess the performance of its employees.

Recording process, payroll and allowance counting, and documentation document still using a manual system that will cause a high human error and will be produced in the longer time.

The company uses only a simple data backup procedure, and they need a longer time if company looking for another information, so if there are any losing or data crash and there's no a new data changing.

Payroll report are combined with the another spending elements, so it make any difficulty to choose the specific type of spending. Incomplete payroll report will make the management need more time to get detailed information to take an effective and efficient decision.

\section{Problem Solving}

Several solutions to the problems happening in the company is as follows:

Recommend for using the finger printing media in recording the employee's attendance. By this tools, company can minimize the possibility of fraud happened through the attendance data by the employees

Recommend the bank service to send the allowance payment, so it can minimize the risk happened in the spending that caused by the personnel and administration supervisor and it also can make a process faster

Designing a new document about the assessment of employee's performance. This thing must be counted to tell the information about how's the employee's performance overall to help the management making a decision in represent the performance.

Using a computerized and integrated system so the company can reduce the human eror in recording, payroll and allowance counting, and take a short time to make a new document.

Recommend the company to use a database to simplify on data's searching that need to completing the information of company and anticipating losing or crashing on data

Design a special report about a payroll system to make it into a group of the same data and it will simplify the recording, searching, and checking the company's spending for the payroll of employees. Design a payroll report completely to help the management in making effective and efficient decision.

\section{Recommending System Design}

In the payroll system, it started when the employee comes to start the job, the employee have to tapping the absence by finger printing and automatically it will connect to the attendance list. So that if the work time was finish. Personnel and administration supervisor can give a description on the attendance list if the employee can't attend with or no a clear causes. So that if the employee get an external task or want to get a permit in the working hours, so the Personnel and administration supervisor will input the data into the system and print the Out Permit Form then save the form to 
give the description about the employee into the attendance list. Another process when the employee want to take a holiday chance so they have to apply to the Personnel and administration supervisor, then the supervisor have to check it, if they approved it, the supervisor have to input the data into the system and print the form then documentation it.

Every $26^{\text {th }}$ based on attendance list, Personnel and administration supervisor will input data into the system and give it into the manager to give the information of employee's attendance in every month. And based on that list, the manager will get an assessment of that attendance. If the attendance assessment were not satisfy, manager will tell the supervisor to input the data and print the document then give it to the manager to be approval. Then, the attendance list will be inputted by the supervisor and input to the system and print it. Then the supervisor will count the payroll, allowance, transportation, service, and healthy and also the tax service. After that, the form will be send to the manager to be checked, if we found any missed in the form, it will returned to the supervisor.

After that, the supervisor will give the document to the accounting department, then the supervisor will ask an approval to the accounting. After Accounting department approve the form, the supervisor will documentation the form. The other copy form, will give to the head office and as the form received, the head office will prepare the money as it wrote in the document. In every $29^{\text {th }}$, as a funding form, casher will send the employee payroll, and casher will confirm to the supervisor to tell them that the money has been send as it written in the form. Then, the supervisor will print the payroll form and give it to every employee. This document will give a detail about the payroll of every employee.

As a payroll form, the accounting staff will input the data into the system and print the payroll spending report in every month. Then the report will be reported to the manager to be checked and being approved. After being approved, the report will be send to the accounting department. In the end of month, the supervisor will input the data into the system and print the assessment form and give it to the manager to be approved in every month. In the end of years, as the assessment form every month, the supervisor will input the data into the system and print the performance report, and give it to the hotel manager. Then, the document will give to the human resources department to be checked. After that, the accounting staff will input data into the system and print the journal.

Some form that will be produced by the company are:

- Attendance list : the document that will connected by the finger printing media to record the employee's attendance, by this list, we can check the status about the attendance of the employees.

- Out permit form: the document to record permitting of working hour for the employee and it will approved by the supervisor and documentation it

- Holiday chance form : to record a holiday and will be approved by the supervisor and documentation it

- Warning letter: to give a description and record the warning that used to give to the employee.
- $\quad$ Funding asking letter : to record the money and give it to the head office

- Payroll form : to give the information about the payroll of every employees

- Assessment form: represent the all assessment of employee performance in the company.

\section{Conclusion}

Based on analysis and research for a Payroll of Accounting Information System, we can take the following conclusion. In the ongoing system, we can find any problem that will cause any loss to the company, such as recording of attendance process and documentation document will be done manually, a simple data saving will take a risk, and manipulation data in allowance payment system and all the payroll still combines with the other spending, and the last there's still an uncomplete for the payroll report

Design for payroll Accounting information system can support the internal control through the payroll procedure, as the manually control or computerized control so every fraud that caused loss can be minimized. Payroll Accounting Information system must be allowed to produce data and minimized the human eror in counting in every payroll component. Payroll Accounting Information system can produce the efficient payroll in every transaction in the report.

\section{REFERENCES}

[1] E. U. Grande, R. P. Estébanez, and C. M. Colomina, “The impact of Accounting Information Systems (AIS) on performance measures: empirical evidence in Spanish SMEs," in The International Journal of Digital Accounting Research, vol. 11, 2011 pp. $25-43$.

[2] E. G. Mauldin and L. V. Ruchala, "Towards a meta-theory of accounting information systems," in Accounting, Organizations and Society, vol. 24, 1999, pp. 317-331.

[3] H. Sajady, M. Dastgir, and H. H. Nejad, "Evaluation of the Effectiveness of Accounting Information Systems," in International Journal of Information Science \& Technology, vol. 6, no. 2, July 2008, pp. 49-59.

[4] M. Salehi, V. Rostami, and A. Mogadam, "Usefulness of Accounting Information System in Emerging Economy: Empirical Evidence of Iran," in International Journal of Economics and Finance, vol. 2, no. 2, May. 2010, pp. 186-195.

[5] Z. M. Sori, "Accounting Information Systems (AIS) and Knowledge Management: A Case Study", in American Journal of Scientific Research, vol. 4, pp.36-44, EuroJournals Publishing, 2009, from: http://www.eurojournals.com/ajsr_4_04.pdf

[6] H. Xu, "Data quality issues for accounting information systems' implementation: Systems, stakeholders, and organizational factors", in J. of Technology Research, vol. 1, Apr. 2009, from http://www.aabri.com/manuscripts/09189.pdf 